existing structural organization can be inherited during their vegetative growth and division, and is not under genetic control. This is one of the very few examples of inheritance not involving an alteration in DNA. The classic example is the inheritance of ciliary rows that have been inverted by $180^{\circ}$. But it is not just inversion of ciliary rows that can be inherited. Large-scale reversals of asymmetry are possible so that there is a change in intracellular handedness that affects the arrangement of all the cortical structures within its domain.

Ciliates show a remarkable capacity for regeneration and pattern regulation. It is as if the cell is behaving like a classical embryonic gradient field. Frankel has proposed a formal model, based on positional information, which attempts to account for a large number of results. Treating the ciliate as a cylinder, it is assumed that there are both longitudinal and circumferential positional values giving, in effect, a two-dimensional coordinate system, which makes the different parts of the cortical system nonequivalent. One property of the system is its tendency to achieve a continuum of normally spaced positional values, and in this it is similar to the polar coordinate model that has been so successful in accounting for the regeneration of multicellular systems. A key feature of the model is that positional values are interpreted' by the development of specific structures. Both positional value and interpretation are, however, completely without a molecular basis. But as Frankel makes clear, the model provides a partial explanation for a large amount of information which would otherwise be incomprehensible. Moreover, there are few errors of commission, that is, a structure forming where it is not expected.

This brief review does little justice to the richness of the material, the clarity of the exposition, or how well Frankel relates ciliate patterning to that in multicellular organisms. He has written an outstanding book. One can only hope it will encourage others to enter the field. The difficulties in solving the problem are great, but so are the rewards. One cannot but believe that underlying patterning in the single cell is a fundamental biological mechanism that has been taken over by multicellular organisms.

Lewis Wolpert is Professor of Anatomy, University College and Middlesex School of Medicine, Cleveland Street, London W1P 6DP, UK.

- Two new books from Cambridge University Press also address early development. This Side Up by Robert Wall, describes spatial determination in the early development of animals. Price $£ 70, \$ 110$. Morphogenesis by Jonathan Bard, is about the cellular and molecular processes of developmental anatomy. Price $£ 35, \$ 54.50$.

\section{Early blooming}

\section{Ghillean T. Prance}

The Chelsea Gardener. Philip Miller 1691-1771. By Hazel le Rougetel. Natural History Museum Publications, London: 1990. Pp. 212. £14.95, \$29.95.

"MilleR's Gardeners' Dictionary is the most important horticultural work of the eighteenth century" says Professor William T. Stearn, who contributed the final chapter to this book. This is certainly true; indeed, Philip Miller was also the leading British gardener of his century. As the keeper of the Apothecaries' Physic Garden at Chelsea from 1722 to 1770 , he built up the most richly stocked garden in Europe. Miller was both botanist and horticulturalist and his dictionary is the his correspondents were Sir Joseph Banks and Sir Hans Sloane, and a fascinating chapter deals with his transatlantic correspondence, particularly with plant collector John Bartram. Another chapter is about Miller's most valued flowering shrub, the rose. The Provence appears to have been Miller's favourite among the many species and varieties of roses that he cultivated at Chelsea. Miller did not confine his horticulture to the garden directly under his care in Chelsea but advised and exchanged material with many of the great estates of England, such as the garden of the third Duke of Argyll at Whitton which accumulated a large collection of trees. On the death of the duke in 1761, many of the beautiful trees at Whitton were transferred by Lord Bute to Princess Augusta's garden at Kew, the precursor of the Royal Botanic Gardens. Fortunately, Miller's work at Chelsea has been continued by sub-

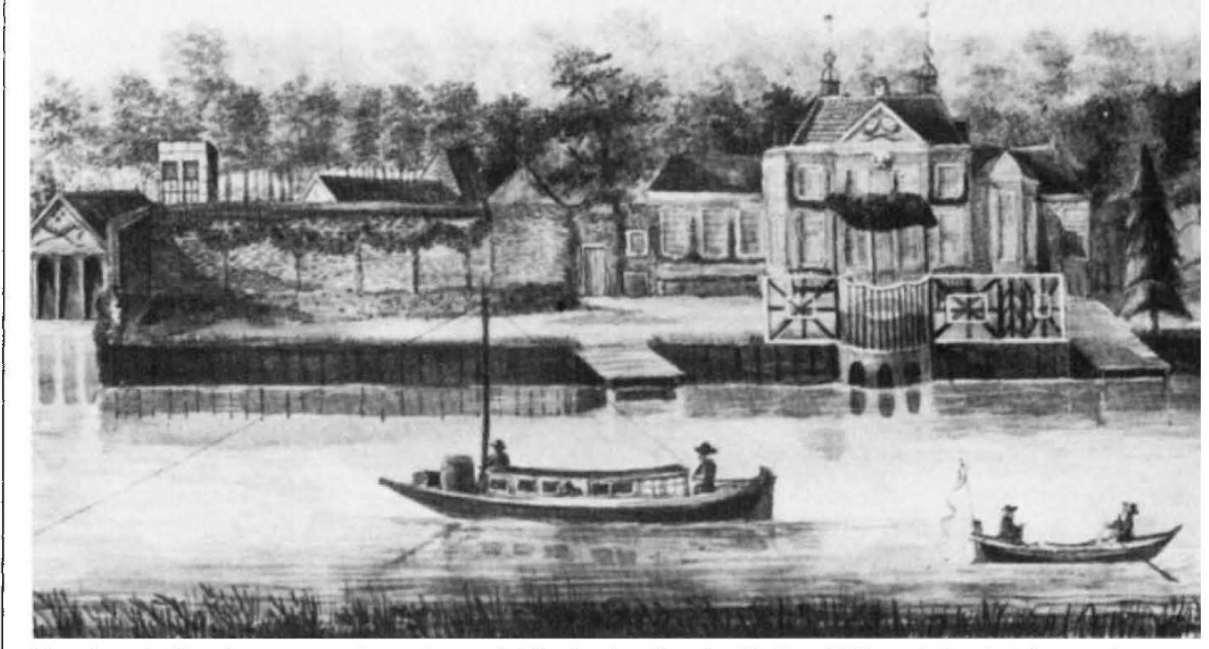

Meerburg, the house and garden of M. de la Court. Philip Miller visited this garden, at Oud-Poelgeest, Holland, in 1727, and was instructed by its gardener on the cultivation of pineapples. (From The Chelsea Gardener.)

source of the original descriptions and names of many species of plants.

Miller was a contemporary of Linnaeus and, in the eighth and last edition of his great work, he adopted the Linnaean system of nomenclature which he had earlier resisted. He was a great correspondent and maintained contact with botanists and plant collectors from all around the world. As a result, he obtained for the Physic Garden many species from Europe, North America, South Africa and the West Indies which were not seen by Linnaeus. Miller named these both from living material and from herbarium specimens, so his dictionary is a work of major importance to taxonomic botany. Many familiar garden plants still bear the name of Miller after their Latin binomials.

This delightful new book about Miller covers many aspects of his life and his influence on the world of botany. Among sequent generations and the Physic Garden is still a testimony to its greatest keeper. This book will make any visitor's trip to today's garden even more interesting.

The book is abundantly illustrated with 16 colour plates and numerous blackand-white drawings carefully selected from Miller's Gardeners' Dictionary and Figures of Plants and engravings of Chelsea. It is attractive and well laid out, and will be of interest both to botanists and to horticulturalists who are interested in the history of their discipline.

Ghillean T. Prance is Director of the Royal Botanic Gardens, Kew, Richmond, Surrey TW9 3AB, UK.

- The Cheisea Physic Garden, 66 Royal Hospital Road, London SW3 4HB, UK, is open to the public on Wednesdays and Sundays from 2 p.m. to 5 p.m. 